\title{
Simulation of a Charged Al203 Film As An Assisting Passivation Layer For a-Si Passivated Contact p- Type Silicon Solar Cells
}

Tian Pu ( $\sim$ sherlock.pu@outlook.com )

Nanjing University of Aeronautics and Astronautics https://orcid.org/0000-0002-9428-2656 Honglie Shen

Nanjing University of Aeronautics and Astronautics https://orcid.org/0000-0002-2759-9880 Quntao Tang Nanjing University of Aeronautics and Astronautics

\section{Research Article}

Keywords: Simulation, charged Al2O3 layer, a-Si passivated contact p-type silicon solar cell, HIT solar cell

Posted Date: February 23rd, 2021

DOl: https://doi.org/10.21203/rs.3.rs-215611/v1

License: (1) This work is licensed under a Creative Commons Attribution 4.0 International License. Read Full License

Version of Record: A version of this preprint was published at Silicon on April 19th, 2021. See the published version at https://doi.org/10.1007/s12633-021-01105-4. 


\section{Abstract}

In this paper, a charged $\mathrm{Al}_{2} \mathrm{O}_{3}$ tunneling film as an assisting for amorphous $\mathrm{Si}$ (a-Si) passivated contact layer is proposed and theoretically simulated for its potential application in improving a-Si passivated contact p-type (a-PC-p) solar cell. The concept is based on an $\mathrm{Ag} / \mathrm{n}^{+} \mathrm{c}-\mathrm{Si} / \mathrm{p} \mathrm{c}-\mathrm{Si} / \mathrm{Al}_{2} \mathrm{O}_{3} / \mathrm{p}^{+} \mathrm{a}-\mathrm{Si} / \mathrm{Al}$ structure. The key feature is the introduction of a charged $\mathrm{Al}_{2} \mathrm{O}_{3}$ layer, which facilitates the tunneling of holes through an $\mathrm{Al}_{2} \mathrm{O}_{3}$ insulator layer accompanied by the reduction of interface defect density $\left(\mathrm{D}_{\text {it }}\right)$. The negative charge in the $\mathrm{Al}_{2} \mathrm{O}_{3}$ layer makes the energy band of p-type c-Si bend upward, realizing the accumulation of holes and repelling of electrons at the c-Si/a-Si interface simultaneously. The influence of interface negative charges $\left(Q_{i t}\right)$ between a-Si and c-Si, $\mathrm{Al}_{2} \mathrm{O}_{3}$ thickness, $\mathrm{Al}_{2} \mathrm{O}_{3}$ bandgap, interface defect density $\left(D_{i t}\right)$ at the a-Si/c-Si interface are systematically investigated on the output parameters of a-PC-p cells. Inserting a charged $\mathrm{Al}_{2} \mathrm{O}_{3}$ film between the c-Si/a-Si interface, a $+4.2 \%$ relative efficiency gain is predicted theoretically compared with the a-PC-p cells without the $\mathrm{Al}_{2} \mathrm{O}_{3}$ layer. Subsequently, the device performance under various temperatures is simulated, and the insertion of a charged $\mathrm{Al}_{2} \mathrm{O}_{3}$ layer obviously decreases the $P_{\max }$ temperature coefficient from $-0.336 \% /{ }^{\circ} \mathrm{C}$ to $-0.247 \% /{ }^{\circ} \mathrm{C}$, which is analogous to that of Heterojunction with Intrinsic Thin layer (HIT) solar cell. The above results demonstrate a better temperature response for a-PC- $p$ cells with a charged $\mathrm{Al}_{2} \mathrm{O}_{3}$ layer, paving a road for its potential application in high-efficiency and high thermal stability a-PC-p solar cells.

\section{Highlights}

- A charged $\mathrm{Al}_{2} \mathrm{O}_{3}$ assisting passivation layer is proposed for a-Si PC-p

- The $\mathrm{Al}_{2} \mathrm{O}_{3}$ layer makes the selective carrier tunneling at the c-Si/a-Si interface.

- $\mathrm{A}+4.2 \%$ relative efficiency gain is predicted theoretically by the $\mathrm{Al}_{2} \mathrm{O}_{3}$

- The insertion of the $\mathrm{Al}_{2} \mathrm{O}_{3}$ layer reduces the $\mathrm{P}_{\max }$ temperature coefficient greatly.

\section{Introduction}

In the last several years, the a-Si/c-Si passivated contact (a-PC) solar cell has attracted a large amount of attention due to its prominent high $\mathrm{V}_{\mathrm{oc}}$ and higher efficiency. A famous example of the a-PC solar cell is the heterojunction technology (HJT) solar cell which achieves very high conversion efficiency by using hydrogenated amorphous silicon (a-Si:H) layer to effectively passivate the amorphous and crystalline silicon (c-Si) interface as well as at the metal contact area ${ }^{[1]}$. Compared with traditional diffusion processed homo-junction solar cells, the most attractive advantages of the a-PC solar cell are its lower deposition temperature $\left(<200{ }^{\circ} \mathrm{C}\right)$ and better cell temperature coefficient $(-0.25 \%)^{[2]}$. As is known to all, the device quality is mainly determined by factors including a-Si emitter quality and interface quality between a-Si and c-Si. Defect states at the a-Si/c-Si interface could induce strong interface recombination in an a-PC solar cell if the interface defect density is larger than $1 \times 10^{13} \mathrm{~cm}^{-2} \cdot \mathrm{eV}^{-1}$. The mid-gap with a low 
interface state can be achieved by the insertion of intrinsic hydrogenated amorphous silicon. However, the narrow process window for depositing intrinsic hydrogenated amorphous silicon makes it very easy to grow epitaxially on the c-Si substrate ${ }^{[3]}$. The detrimental effect of an epitaxially grown interface normally causes a $\mathrm{V}_{\mathrm{oc}}$ of a-PC solar cell lower than $600 \mathrm{mV}$. The defects in the epitaxial film are determined by the energy position within the bandgap and the capture cross-section of the electron and hole. Usually, an abruptness of the a-Si/c-Si interface without any initial epitaxial growth is more preferred. Therefore, a tunnel oxide insulator layer (usually $\mathrm{SiO}_{2}$ ), is adopted to prohibit the epitaxial phenomenon and reduce recombination at the interface ${ }^{[4-5]}$. Generally speaking, the used $\mathrm{SiO}_{2}$ should be as thin as possible to ensure the tunneling process $(<20 \AA)$, while the interface passivation effect will be better if a thicker oxide layer is adopted. As a result, a trade-off between the tunneling process and interface passivation should be considered.

Generally speaking, a solar cell is based on a semiconductor material that absorbs light and then generates excess electrons and holes. The different types of contacts in a solar cell not only conduce to collect the different charge carriers but also serve as a semipermeable membrane so that one contact supports electrons getting across and blocks holes, while the other contact is exactly the opposite. Except being carrier-selective, the contacts are better to passivate the surface defects to ensure that the minority carriers are collected before their recombination. Such contacts can therefore be defined as contact passivation ${ }^{[6]}$. Recently, there has been an increasing interest in the application of tunneling layers for passivation contact in single-junction silicon-based solar cells. The used a-Si stack layer in HIT solar cells ${ }^{[7]}$ and $\mathrm{SiO}_{2}$ /polycrystalline silicon stack layer ${ }^{[8]}$ in high-efficiency n-type silicon solar cells are all, in fact, contact passivation structures. Therefore, the contact passivation structure is usually made of an ultrathin insulator layer and a highly doped semiconductor layer. The used insulator materials can be positively charged layers, i.e., a- $\mathrm{SiN}_{\mathrm{x}}: \mathrm{H}^{[9]}$ and thermal $\mathrm{SiO}_{2}{ }^{[10]}$, which can lead to an effective surface passivation result on lightly doped $\mathrm{n}$ - or $\mathrm{p}$-type substrate, as well as some negatively charged layer such as $\mathrm{Al}_{2} \mathrm{O}_{3}{ }^{[11]}$. Negative charges in $\mathrm{Al}_{2} \mathrm{O}_{3}$ are particularly suited to passivate the backside of the $p$-type solar cell. It is expected that the negative charges in $\mathrm{Al}_{2} \mathrm{O}_{3}$ can repel electrons and accumulate holes at the interface between a-Si and $\mathrm{c}-\mathrm{Si}$, which increases the probability of tunneling through the $\mathrm{Al}_{2} \mathrm{O}_{3}$ layer. Aluminum oxide $\left(\mathrm{Al}_{2} \mathrm{O}_{3}\right)$ has potentially been used as an optional passivation material to standard a$\mathrm{SiN}_{\mathrm{x}}: \mathrm{H}$. The application of $\mathrm{Al}_{2} \mathrm{O}_{3}$ here could be summarized by two important trends. First, the photovoltaic (PV) industry has recently transferred the Al-back surface field (Al-BSF) cell to a dielectrically rear passivated cell[ ${ }^{[12-14]}$. This rear side passivated structure leads to a lower surface recombination loss, better light reflection inside the cell, and less suffered wafer bow for thinner wafers ${ }^{[15-17]}$. A passivated rear side is believed necessary for higher conversion efficiency and the possibility of thinner Si wafers application. Though the ultrathin $\mathrm{SiO}_{2}$ layer has been widely used in a-PC solar cells, the use of an ultrathin $\mathrm{Al}_{2} \mathrm{O}_{3}$ layer as a tunnel oxide layer in contact passivation structure is rarely reported. Therefore, it is necessary for understanding how the parameters affecting tunneling, for example, the negative 
charges $\left(Q_{i t}\right)$ in the a-Si and c-Si interface, $\mathrm{Al}_{2} \mathrm{O}_{3}$ thickness, interface defect density $\left(\mathrm{D}_{\mathrm{it}}\right)$ between a-Si and c-Si.

In this paper, a p-type c-Si substrate a-Si passivated contact solar cell based on Ag/ $\mathrm{n}^{+} \mathrm{c}-\mathrm{Si} / \mathrm{p} \mathrm{c-}$ $\mathrm{Si} / \mathrm{Al}_{2} \mathrm{O}_{3} / \mathrm{p}^{+} \mathrm{a}-\mathrm{Si} / \mathrm{Al}$ structure has been developed to study the variation of $\mathrm{Q}_{\mathrm{it}}$ between a-Si and c-Si, $\mathrm{Al}_{2} \mathrm{O}_{3}$ thickness, $\mathrm{Al}_{2} \mathrm{O}_{3}$ bandgap and $\mathrm{D}_{\text {it }}$ at the a-Si/c-Si interface on a-PC cell performance using AFORS-HET software. The purpose of this paper is to investigate the influence of the charged $\mathrm{Al}_{2} \mathrm{O}_{3}$ layer on a-PC cell's performance, so the reference cell is not optimized.

\section{Simulation Models}

\subsection{Tunneling theory}

As direct quantum tunneling, the calculation of electron tunnel current $\mathrm{J}_{\mathrm{e}}$, tun is based on the Tsu-Esaki equation ${ }^{18]}$ in semiconductor-insulator-semiconductor (SIS) structures:

$$
\mathrm{J}_{e, t u n}=\frac{4 \pi q m^{*}}{h^{3}} \int_{E_{\min }}^{+\infty} T(E) N(E) d E
$$

where $q$ is the elementary charge, $E_{\min }$ is the minimum conduction band edge energy to have tunneling effect, $m^{*}$ is the tunneling effective mass and $h$ is Planck's constant. The barrier transparency $T(E)$ gives the probability of an electron with the energy $E$ through the barrier to the tunnel.

With known effective masses for silicon, the result outside the integration sign is a constant. As a result, the tunneling current is dominated by the quasi-Fermi levels, the energy of the charge carriers and the transmission coefficient. This coefficient is the ratio of the outgoing compare with incoming flux, is found using the transfer matrix method to solve the Schrödinger equation. The major parameters are the height of the energy barrier, the mass of the tunneling effect and the thickness of the oxide.

\subsection{Simulation parameters}

We use the 1D simulation software "Automat FOR Simulation of HETerostructure" (AFORS-HET) developed at the Helmholtz Zentrum Berlin ${ }^{[19]}$ to perform the numerical simulation in this case. AFORSHET could solve one-dimensional semiconductor equations related to Shockley-Reed-Hall statistics. It utilizes an optical model based on the Lambert-Beer law for calculating the optical parameters. In this article's simulation, we assumed that the metal contacts are a flat band and the solar radiation AM 1.5 with a power density of $100 \mathrm{~mW} / \mathrm{cm}^{2}$ is introduced as a light source. The gap statistics of various types of a-Si:H layers and c-Si wafer are defined as a default value in the AFORS-HET configuration. Simulated cell structure with the position of the different layers is presented in Fig.1. The layer's given parameters are presented in Table 1.

Table 1 Input parameters used in the present simulation 


\begin{tabular}{|c|c|c|c|c|}
\hline Parameters & $c-S i\left(n^{+}\right)$ & c-Si (p) & ALD $\mathrm{Al}_{2} \mathrm{O}_{3}$ & a-Si:H $\left(p^{+}\right)$ \\
\hline Layer thickness $(\mathrm{cm})$ & $3.0 \times 10^{-5}$ & 0.018 & Variable & $5 \times 10^{-7}$ \\
\hline Dielectric constant & 11.9 & 11.9 & 6 & 11.9 \\
\hline Electron affinity $(\mathrm{eV})$ & 4.05 & 4.05 & 2.5 & 3.9 \\
\hline Bandgap (eV) & 1.12 & 1.12 & Variable & 1.72 \\
\hline Effective conduction band density $\left(\mathrm{cm}^{-3}\right)$ & $8.95 \times 10^{18}$ & $2.8 \times 10^{19}$ & & $1.0 \times 10^{20}$ \\
\hline Effective valence band density $\left(\mathrm{cm}^{-3}\right)$ & $8.44 \times 10^{18}$ & $2.8 \times 10^{19}$ & & $1.0 \times 10^{20}$ \\
\hline Electron mobility $\left(\mathrm{cm}^{2} / \mathrm{Vs}\right)$ & 119.5 & 1041 & & 20 \\
\hline Hole mobility $\left(\mathrm{cm}^{2} / \mathrm{Vs}\right)$ & 159.9 & 413 & & 5 \\
\hline Acceptor doping concentration $\left(\mathrm{cm}^{-3}\right)$ & 0 & $1.5 \times 10^{16}$ & & $1.0 \times 10^{20}$ \\
\hline Donor doping concentration $\left(\mathrm{cm}^{-3}\right)$ & $10^{19}$ & 0 & & 0 \\
\hline $\begin{array}{l}\text { Thermal velocity of electrons } \\
\qquad(\mathrm{cm} / \mathrm{s})\end{array}$ & $1.0 \times 10^{7}$ & $1.0 \times 10^{7}$ & & $1.0 \times 10^{7}$ \\
\hline $\begin{array}{l}\text { Thermal velocity of holes } \\
\qquad(\mathrm{cm} / \mathrm{s})\end{array}$ & $1.0 \times 10^{7}$ & $1.0 \times 10^{7}$ & & $1.0 \times 10^{7}$ \\
\hline Layer density $\left(\mathrm{g} / \mathrm{cm}^{3}\right)$ & 2.328 & 2.328 & & 2.328 \\
\hline Auger recombination coefficient for electron $\left(\mathrm{cm}^{6} / \mathrm{s}\right)$ & 0 & $2.2 \times 10^{-31}$ & & 0 \\
\hline Auger recombination coefficient for electron $\left(\mathrm{cm}^{6} / \mathrm{s}\right)$ & 0 & $9.9 \times 10^{-32}$ & & 0 \\
\hline Direct band-to-band recombination coefficient $\left(\mathrm{cm}^{3} / \mathrm{s}\right)$ & $9.5 \times 10^{-15}$ & $9.5 \times 10^{-15}$ & & 0 \\
\hline fixed charge density $\left(\mathrm{cm}^{-2}\right)$ & & & Variable & \\
\hline
\end{tabular}

At the rear side hetero-interface, defects are considered using a $1 \mathrm{~nm}$ thick highly defective c-Si interfacial layer which contains two Gaussian distributed density of states (DOS) ${ }^{[20]}$. The Gaussian distributions of donor-like and the acceptor-like have their maximum at $0.56 \mathrm{eV}$ and $0.76 \mathrm{eV}$ above the valence band $\left(\mathrm{E}_{\mathrm{v}}\right)$. The standard deviation of both distributions is $0.2 \mathrm{eV}$ and the electron and holes capture cross-sections $\left(\sigma_{e}, \sigma_{\mathrm{h}}\right)$ are $1 \times 10^{-14} \mathrm{~cm}^{-2}$. Their heights are adjusted to the equivalent interface defect densities $\left(\mathrm{cm}^{-2}\right)$, which is yield targeted.

Regarding the carrier transport mechanism, we assume drift-diffusion for c-Si/c-Si (homo-interfaces) and consider tunneling thermionic emission for c-Si/a-Si:H (hetero-interfaces). Here we should also consider a high doping level of the added a-Si layer will induce the bandgap narrowing.

The electrical current through the two semiconductors' interface is virtually the current that would flow through a fictitious insulating layer by tunneling in this simulation using AFROS-HET software. The conduction mechanism in this simulated structure could be explained as a hole tunneling from the valence band of the base $\mathrm{p}$-type c-Si through the $\mathrm{Al}_{2} \mathrm{O}_{3}$ layer, then into the $\mathrm{p}^{+} \mathrm{a}$-Si:H layer. The effective mass of bulk $\mathrm{Al}_{2} \mathrm{O}_{3}$ is 3-10 $\mathrm{m}_{0}$, while an effective mass of $0.33 \mathrm{~m}_{0}$ has been found for tunnel thin layers ${ }^{[21]}$. So the input effective mass of $\mathrm{Al}_{2} \mathrm{O}_{3}$ is set to $0.33 \mathrm{~m}_{0}$. Bulk $\mathrm{Al}_{2} \mathrm{O}_{3}$ in the crystalline phase has a 
bandgap of about $8.8 \mathrm{eV}$. For the atomic layer deposition deposited amorphous $\mathrm{Al}_{2} \mathrm{O}_{3}$ layer has a bandgap of about $6.4 \mathrm{eV}^{[22]}$. This has been used unless stated otherwise. The dielectric constant and electron affinity values of the ultrathin $\mathrm{Al}_{2} \mathrm{O}_{3}$ layer are set according to the results reported in the literature [22]

\section{Results And Discussion}

Along with the introduction of Aluminum oxide $\left(\mathrm{Al}_{2} \mathrm{O}_{3}\right)$ comes the introduction of atomic layer deposition (ALD) in the photovoltaic industry. ALD is different from conventional plasma-enhanced chemical vapor deposition tools due to the strict separation of the process gases in two half-cycles during deposition, resulting in a self-limited layer-by-layer growth. The strength of ALD is precisely thickness control and very good deposition uniformity over large area surfaces. Generally speaking, the excellent passivation performance of $A L D ~ \mathrm{Al}_{2} \mathrm{O}_{3}$ originates from the combination of low $\mathrm{D}_{\text {it }}$ (chemical passivation) and high $\mathrm{Q}_{\text {it }}$ (field-effect passivation) ${ }^{[23]}$. The as-deposited thermal $A L D ~ \mathrm{Al}_{2} \mathrm{O}_{3}$ usually possesses a relatively low $\mathrm{D}_{\text {it }}$ accompanied with a low value of $Q_{i t}$ while the as-deposited plasma ALD provides high $D_{i t}$ and high $Q_{i t}$. With extra annealing treatment, both ALD processes show lower $D_{i t} \leq 1 \times 10^{11} \mathrm{~cm}^{-2[24-25]}$. Regarding the field-effect passivation, the thermal ALD-based $\mathrm{Al}_{2} \mathrm{O}_{3}$ film exhibits especially low $\mathrm{Q}_{\text {it }}$ of the order of $10^{11}$ $\mathrm{cm}^{-2}$ before annealing comparing to plasma ALD with $Q_{i t}$ of the order of $10^{12} \mathrm{~cm}^{-2}$. Also, the highest $Q_{i t}$ value for plasma ALD can reach $10^{13} \mathrm{~cm}^{-2[26-28]}$ after annealing. Therefore, for the $A L D \mathrm{Al}_{2} \mathrm{O}_{3}$ film, $\mathrm{Q}_{i t}$ can be adjusted from $1 \times 10^{10} \sim 10^{13} \mathrm{~cm}^{-2}$ by choosing different ALD processes and post-annealing treatment. To investigate the influence of $\mathrm{Q}_{i t}$ at $\mathrm{p}$-type c-Si/ALD $\mathrm{Al}_{2} \mathrm{O}_{3}$ interface on simulated a-PC-p cell's output parameters, $Q_{i t}$ is adjusted from $1 \times 10^{10} \sim 10^{13} \mathrm{~cm}^{-2}$ with $D_{\text {it }}$ fixed at $10^{11} \mathrm{~cm}^{-2}$. Fig. 2 presents the simulated a-PC-p cell's output parameters versus $Q_{i t}$. It is seen that the cell's performance is enhanced with increasing $Q_{i t}$ from $10^{10} \mathrm{~cm}^{-2}$ to $10^{13} \mathrm{~cm}^{-2}$. In the low $Q_{i t}\left(<10^{12} \mathrm{~cm}^{-2}\right)$ region, the amount of $Q_{i t}$ is not enough to assist hole tunneling through the $\mathrm{Al}_{2} \mathrm{O}_{3}$ layer, as a result of which low $\mathrm{J}_{\mathrm{sc}}$ and low $\mathrm{FF}$ appear. When $Q_{i t}$ increases from $10^{12} \mathrm{~cm}^{-2}$ to $10^{13} \mathrm{~cm}^{-2}, J_{\mathrm{sc}}$ and efficiency increase while FF rarely changes. Therefore, it is suspected that enough amount of $Q_{i t}$ can ensure the tunneling process even though a dielectric layer is used. This is consistent with the result reported in the literature ${ }^{[28]}$.

As the $\mathrm{ALD} \mathrm{Al} \mathrm{O}_{2} \mathrm{O}_{3}$ layer thickness can influence the tunneling of carriers, various levels of $\mathrm{Al}_{2} \mathrm{O}_{3}$ layer thickness are adopted to study its effect on simulated a-PC-p cell's output parameters (shown in Fig.3). To understand how $\mathrm{Q}_{i t}$ affects the $\mathrm{Al}_{2} \mathrm{O}_{3}$ layer of different thicknesses, $\mathrm{Al}_{2} \mathrm{O}_{3}$ layers of various thicknesses with and without $\mathrm{Q}_{i t}$ are introduced (shown in Fig.3). For the $\mathrm{Al}_{2} \mathrm{O}_{3}$ layer without $\mathrm{Q}_{i t}$, the cell's FF decreases rapidly from $80.89 \%$ to $49.33 \%$ with $\mathrm{Al}_{2} \mathrm{O}_{3}$ thickness increasing from $0.2 \mathrm{~nm}$ to $0.4 \mathrm{~nm}$. And $\mathrm{FF}, \mathrm{J}_{\mathrm{sc}}$ and efficiency are reduced to $40.66 \%, 0.32 \mathrm{~mA} / \mathrm{cm}^{-2}$ and $0.087 \%$, respectively, when $\mathrm{Al}_{2} \mathrm{O}_{3}$ thickness further increases to $1 \mathrm{~nm}$. However, for the $\mathrm{Al}_{2} \mathrm{O}_{3}$ layer with $-10^{13} \mathrm{~cm}^{-2} \mathrm{Q}_{i t}$, both $\mathrm{FF}$ and efficiency of the cell rarely change even when increasing $\mathrm{Al}_{2} \mathrm{O}_{3}$ thickness to $1 \mathrm{~nm}$. This demonstrates the 
vital role $Q_{i t}$ plays in carrier tunneling. When $\mathrm{Al}_{2} \mathrm{O}_{3}$ thickness exceeds $1 \mathrm{~nm}$, the cell with $-10^{13} \mathrm{~cm}^{-2} \mathrm{Q}_{i t}$ loses its $\mathrm{J}_{\mathrm{sc}}$ and efficiency rapidly, while its FF still rarely changes. Theoretically, the thicker the $\mathrm{Al}_{2} \mathrm{O}_{3}$ layer is, the lower the tunneling probability $(\mathrm{T}(\mathrm{E}))$ for carriers will be. Therefore, a thinner $\mathrm{Al}_{2} \mathrm{O}_{3}$ is desired for a high tunneling current. Besides, the added $Q_{i t}$ facilitates the alignment of the energy bands for both $\mathrm{c}$-Si and a-Si, and causes the accumulation of holes at their interface, which results in a higher built-in potential. Therefore, the enhanced built-in potential facilitates the tunneling of holes through the barrier.

According to the simulated results shown in Fig.2 and Fig.3, $\mathrm{Q}_{i t}$ at the c-Si/a-Si interface have a significant influence on carrier transport through the $\mathrm{Al}_{2} \mathrm{O}_{3}$ dielectric layer. $\mathrm{Q}_{i \mathrm{t}}$ can maintain the successful tunneling of carriers without degrading the cell's performance. To figure out how $\mathrm{Q}_{i \mathrm{t}}$ influences the transport of carriers through the $\mathrm{Al}_{2} \mathrm{O}_{3}$ dielectric layer, band diagram and carrier distribution with the position of two different cells are calculated and compared. The $\mathrm{Al}_{2} \mathrm{O}_{3}$ dielectric layer thickness for both cells is fixed at $1 \mathrm{~nm}$. The only difference between the two cells is that one cell has a $Q_{i t}$ of $-10^{13} \mathrm{~cm}^{-2}$, while the other has a $Q_{i t}$ of $0 \mathrm{~cm}^{-2}$. As shown in Fig.4 (a) and (b), the band diagram of the cell with a $Q_{i t}$ of $-10^{13} \mathrm{~cm}^{-2}$ bends upward compared to the other cell, indicating that the high $\mathrm{Q}_{\mathrm{it}}$ leads to an accumulation of holes at the interface. Fig.4 (c) shows the density of electron and hole at the c-Si/a-Si interface, a large number of holes with an order of $10^{13} \mathrm{~cm}^{-3}$ accumulated on the c-Si side accompanied by a smaller amount of electrons for the cell with a $Q_{i t}$ of $10^{13} \mathrm{~cm}^{-2}$. Cell with a $Q_{i t}$ of 0 only has a much smaller amount of electrons and holes on the c-Si side. This reveals the fact that $Q_{i t}$ can influence the carrier distribution at the c-Si/a-Si interface and thus the selective transport of carriers through the dielectric layer. Based on the above three figures, a schematic band diagram illustrating how the charged $\mathrm{Al}_{2} \mathrm{O}_{3}$ layer affecting the transport behavior of electrons and holes is shown in Fig.4 (d). As can be seen, the charged $\mathrm{Al}_{2} \mathrm{O}_{3}$ layer behaves like a filter which can allow the transport of holes through it with repelling electrons backward.

The oxide bandgap $\left(\mathrm{E}_{\mathrm{g}}\right)$ can also affect the magnitude of the effect caused by the charges. A difference in the bandgap of $\mathrm{Al}_{2} \mathrm{O}_{3}$ has been figured for different deposition processes, there is a variation from 6.2 $\mathrm{eV}$ to $7.0 \mathrm{eV}$ was found in the literature ${ }^{[29,30]}$. In Fig.5, the simulated a-PC-p cell's four output parameters as a function of the $\mathrm{Al}_{2} \mathrm{O}_{3}$ bandgap are shown for $\mathrm{Q}_{\text {if }}$ value of $-10^{13} \mathrm{~cm}^{-2}$. The cell's efficiency is mainly influenced by the change of $J_{s c}$ and $F F$. When $E_{g}$ is less than $6.7 e V$, the decrease of efficiency along with increasing $E_{g}$ is due to the decrease of FF. However, when $E_{g}$ is bigger than $6.7 \mathrm{eV}$, the loss of efficiency is mostly determined by the decrease of $\mathrm{J}_{\mathrm{sc}}$. It is expected that the barrier height at the c-Si/a-Si interface can be modeled by choosing the $\mathrm{Al}_{2} \mathrm{O}_{3}$ layer of different $\mathrm{E}_{\mathrm{g}}$. Therefore, selecting a bigger $\mathrm{E}_{\mathrm{g}} \mathrm{Al}_{2} \mathrm{O}_{3}$ layer means higher barrier height at the c-Si/a-Si interface, which results in a relatively low tunneling probability, and thus a low FF and a low $\mathrm{J}_{\mathrm{sc}}$.

We know that the interface defect density $\left(D_{i t}\right)$ has a great influence on c-Si/a-Si interface recombination. The distribution of $D_{i t}$ at the c-Si/a-Si interface is a state's superposition near band edges and states. 
These states include surface pretreatment-induced strain bonds, bonds between adsorbates, dangling bonds, and atoms of different oxide layers leading to several groups of interface states. The minimum value for these interface state distributions can be considered as a measurement of the electronic quality of the wafer and interface. Fig. 6 shows the dependence of simulated a-PC-p cells' output parameters on $D_{i t}$. As can be seen, the output parameters of a-PC-p cells, whether with or without the charged $\mathrm{Al}_{2} \mathrm{O}_{3}$ layer, tend to decrease with increasing $D_{i t}$. When $D_{i t}$ is less than $1 \times 10^{13} \mathrm{~cm}^{-2}$, the a-PC-p cell with charged $\mathrm{Al}_{2} \mathrm{O}_{3}$ layer possesses a higher efficiency than that without charged $\mathrm{Al}_{2} \mathrm{O}_{3}$ layer. However, the tendency operates in the opposite way when $D_{i t}$ is over $1 \times 10^{13} \mathrm{~cm}^{-2}$, indicating that the $D_{\text {it }}$ can have different effects on cell efficiency for different cells in different $D_{i t}$ regions. As is known to all, $D_{i t}$ at the a-Si/c-Si interface is more than $1 \times 10^{13} \mathrm{~cm}^{-2}$ and the $\mathrm{Al}_{2} \mathrm{O}_{3}$ layer can supply a certain extent of interface passivation. Therefore, the a-PC-p cell's efficiency can be improved by inserting charged $\mathrm{Al}_{2} \mathrm{O}_{3}$ at the a-Si/c-Si interface. Compared with directly deposited a-Si on the c-Si surface, the presence of the charged $\mathrm{Al}_{2} \mathrm{O}_{3}$ can reduce $\mathrm{D}_{\text {it }}$ and thus higher efficiency can be obtained.

Fig.7 (a) shows a comparison of the I-V characteristics of a simulated cell with only a-Si and with a-Si plus $\mathrm{Al}_{2} \mathrm{O}_{3}$ at c-Si/p+ $\mathrm{p}^{+}$a-Si interface, assuming a fixed interface charge density $\left(\mathrm{Q}_{\mathrm{it}}\right)$ of $-1 \times 10^{13} \mathrm{~cm}^{-2}$. The simulation shows that there is a large efficiency gain ( $4.2 \%$ relative) when changing from a pure a-Si to aSi plus $\mathrm{Al}_{2} \mathrm{O}_{3}\left(\mathrm{Q}_{\mathrm{it}}=-1 \times 10^{13} \mathrm{~cm}^{-2}\right)$ at the c-Si/Al interface. Notably, there is a change of the I-V parameters of the solar cells, i.e., not only an improvement in $\mathrm{V}_{\mathrm{oc}}$ and $\mathrm{J}_{\mathrm{SC}}$, but also a reduction in $\mathrm{FF}$ (see in the inset table in Fig.7 (a)). $\mathrm{V}_{\text {oc }}$ is improved by reducing the interface recombination within the hole collecting region. Compared with pure $\mathrm{p}^{+} \mathrm{a}-\mathrm{Si}$, the addition of a charged $\mathrm{Al}_{2} \mathrm{O}_{3}$ layer can reduce a partial portion of $D_{i t}$ by saturating some dangling bonds at the c-Si/p $p^{+}$a-Si interface $\left(D_{\text {it }}\right.$ is reduced from $10^{13} \mathrm{~cm}^{-2}$ to $10^{11}$ $\mathrm{cm}^{-2}$ ). A relative $\mathrm{J}_{\mathrm{sc}}$ boost of $5.4 \%$ is observed for the cell with the $\mathrm{Al}_{2} \mathrm{O}_{3}$ layer. Comparing the spectral response of simulated cell with only a-Si and with a-Si plus $\mathrm{Al}_{2} \mathrm{O}_{3}$ at c-Si/p $\mathrm{p}^{+}$a-Si interface, it is seen that the external quantum efficiency (EQE) increase from $800 \mathrm{~nm}$ to $1100 \mathrm{~nm}$ (seen in Fig.7 (b)), which is the absorption region of the backside. Below $800 \mathrm{~nm}$, the spectral response is almost the same. In the wavelength region from $800 \mathrm{~nm}$ to $1000 \mathrm{~nm}$, EQE increases. As the front side is the same for both cells, the change of EQE between $800 \sim 1000 \mathrm{~nm}$ must be due to the insertion of the $\mathrm{Al}_{2} \mathrm{O}_{3}$ layer at the $\mathrm{c}-\mathrm{Si} / \mathrm{p}^{+}$ a-Si interface. It is expected as light in this region is mostly absorbed in the $180 \mu \mathrm{m}$ thick p-type base, $\mathrm{Q}_{i t}$ increases built-in potential at c-Si/p $\mathrm{p}^{+}$a-Si interface which ultimately boosts the number of holes collected at the cell's backside. This can mostly stem from the enhanced interface passivation effect due to the $\mathrm{Al}_{2} \mathrm{O}_{3}$ layer. Though a relative FF decrease of $3.0 \%$ occurs, which may be due to the insertion of $1 \mathrm{~nm}$ $\mathrm{Al}_{2} \mathrm{O}_{3}$ layer, a high $\mathrm{FF}$ still maintains in comparison to the $\mathrm{Al}_{2} \mathrm{O}_{3}$ layer without $\mathrm{Q}_{i t}$ (as discussed in Fig.3). As discussed before, the cell with the $\mathrm{Al}_{2} \mathrm{O}_{3}$ layer and $\mathrm{Q}_{\text {it }}$ has a higher built-in potential, and thus enhances hole collection which leads to a relatively high FF.

To evaluate the device performance under various temperatures, the temperature response of the a-PC-p cells with and without charged $\mathrm{Al}_{2} \mathrm{O}_{3}$ layer is shown in Fig.8, where the efficiency can also represent the 
maximum output power. The temperature dependences of $\mathrm{V}_{\mathrm{oc}}, \mathrm{J}_{\mathrm{Sc}}, \mathrm{FF}$ and efficiency are illustrated by Fig.8 (a)-(d), respectively. As the temperature increases from $26.85^{\circ} \mathrm{C}$ to $76.85{ }^{\circ} \mathrm{C}, \mathrm{J}_{\mathrm{sc}}$ is enhanced; whereas both $\mathrm{V}_{\text {oc }}$ and efficiency drop; FF fluctuates as the temperature changes. Based on the simulated results, a linear fitting is adopted to calculate the temperature coefficients of $\mathrm{V}_{\mathrm{oc}}, \mathrm{J}_{\mathrm{Sc}}$, FF and efficiency, respectively. The obtained temperature coefficients for both cells are listed in Table 2. As can be seen, the insertion of a charged $\mathrm{Al}_{2} \mathrm{O}_{3}$ layer drops the $\mathrm{P}_{\max }$ temperature coefficient from $-0.336 \% /{ }^{\circ} \mathrm{C}$ to $-0.247 \%$ / ${ }^{\circ} \mathrm{C}$, indicating that the output power degrades less with increasing working temperature. Simultaneously, the $\mathrm{V}_{\text {oc }}$ temperature coefficient also drops for the better interface passivation of charged $\mathrm{Al}_{2} \mathrm{O}_{3}$ layer. The above results demonstrated a better temperature response for the a-PC-p cell with a charged $\mathrm{Al}_{2} \mathrm{O}_{3}$ layer, paving a road for its potential application in high-efficiency and high thermal stability a-PC-p solar cells.

Table 2 Simulated temperature coefficients of $\mathrm{V}_{\mathrm{OC}}, \mathrm{J}_{\mathrm{SC}}, \mathrm{FF}$ and efficiency.

Sample

a-Si
$\mathbf{P}_{\max }$

$-0.336 \%$
$-0.270 \%$

$+0.014 \%$

\section{a-Si $+\mathrm{Al}_{2} \mathrm{O}_{3}$ with $-1 \times 10^{13}$}

$-0.247 \%$

$-0.223 \%$

$+0.006 \%$

\section{$\mathrm{cm}^{-2}$ charges}

\section{Conclusions}

In this study, we theoretically investigate the charged $\mathrm{Al}_{2} \mathrm{O}_{3}$ film as an assisting passivation layer in improving the performance of the p-type silicon-based a-Si passivated contact solar cell $\left(\mathrm{Ag} / \mathrm{n}^{+} \mathrm{c}-\mathrm{Si} / \mathrm{p} \mathrm{c}-\right.$ $\mathrm{Si} / \mathrm{Al}_{2} \mathrm{O}_{3} / \mathrm{p}^{+} \mathrm{a}$-Si/Al structure). The purpose of the charged $\mathrm{Al}_{2} \mathrm{O}_{3}$ tunnel film is to realize the accumulation of holes and simultaneously to enhance the c-Si/a-Si interface passivation, which facilitates the tunneling of holes through the $\mathrm{Al}_{2} \mathrm{O}_{3}$ insulator layer and the reduction of interface defect density $\left(\mathrm{D}_{\text {it }}\right)$ respectively. Through the systematic optimization of interface negative charges $\left(\mathrm{Q}_{\mathrm{it}}\right)$ between a-Si and c$\mathrm{Si}, \mathrm{Al}_{2} \mathrm{O}_{3}$ thickness, $\mathrm{Al}_{2} \mathrm{O}_{3}$ bandgap, and interface defect density $\left(\mathrm{D}_{\mathrm{it}}\right)$ at a-Si/c-Si interface, a $+4.2 \%$ relative efficiency gain is predicted theoretically compared with the a-PC-p cell without $\mathrm{Al}_{2} \mathrm{O}_{3}$ layer. Based on the temperature-dependent investigation of output parameters of both a-PC-p cells, the decrease of the $\mathrm{P}_{\max }$ temperature coefficient from $-0.336 \% /{ }^{\circ} \mathrm{C}$ to $-0.247 \% /{ }^{\circ} \mathrm{C}$ is observed by the insertion of a charged 
$\mathrm{Al}_{2} \mathrm{O}_{3}$ layer. The above results demonstrate the better performance of a-PC-p cell with a charged $\mathrm{Al}_{2} \mathrm{O}_{3}$ layer, indicating its potential application in high-efficiency and high thermal stability a-PC-p solar cells.

\section{Declarations}

\section{Funding statement}

This work has been financially supported by the National Nature Science Foundation of China (61774084), the open project of Key Laboratory of Materials Preparation and Protection for Harsh Environment, Ministry of Industry and Information Technology (XCA20013-3) and the Special Scientific Innovation Fund of Sihong County (H201901).

\section{Conflict of Interest}

We declare that we have no financial and personal relationships with other people or organizations that can inappropriately influence our work, there is no professional or other personal interest of any nature or kind in any product, service and/or company that could be construed as influencing the position presented in, or the review of, the manuscript entitled.

\section{Author contributions}

Conceptualization, Tian Pu.; software, Quntao Tang.; formal analysis, Tian Pu.; investigation, Tian Pu., Quntao Tang; resources, Honglie Shen.; data curation, Quntao Tang; writing-original draft preparation, Tian Pu.; writing-review and editing, Quntao Tang., Honglie Shen.; visualization, Tian Pu.; project administration, Honglie Shen.; funding acquisition, Honglie Shen. All authors have read and agreed to the published version of the manuscript.

\section{Availability of data and material}

The datasets generated during and/or analysed during the current study are available from the corresponding author on reasonable request.

\section{Compliance with ethical standards}

Conflict of Interest. The authors declare that they have no conflict of interest.

Research involving human participants and/ or animals. Not applicable

Informed consent. Informed consent was obtained from all individual participants included in the study.

\section{Consent to participate}

Not applicable 


\section{References}

1. Park H, Lee YJ, Park J et al (2018) Front and Back TCO Research Review of a-Si/c-Si Heterojunction with Intrinsic Thin Layer (HIT) Solar Cell[J]. Trans Electr Electron Mater 19:165-172

2. Haschke J, Dupré O, Boccard M et al (2018) Silicon heterojunction solar cells: Recent technological development and practical aspects - from lab to industry[J]. Solar Energy Materials Solar Cells 187(1):140-153

3. Balaji P, Dauksher WJ, Bowden SG et al (2020) Improving surface passivation on very thin substrates for high efficiency silicon heterojunction solar cells[J]. Sol Energy Mater Sol Cells 216:110715

4. Liu W, Meng F, Zhang X et al (2015) Evolution of native oxide layer at a-Si:H/c-Si interface and its influence on silicon heterojunction solar cell.[J]. Angew Chem 51(3):748-751

5. Choi S, Min KH, Jeong MS (2017) Structural evolution of tunneling oxide passivating contact upon thermal annealing[J]. Scientific reports 7(1):12853

6. Limodio G, Yang G, Ge H et al (2019) Front and rear contact Si solar cells combining high and low thermal budget Si passivating contacts[J]. Sol Energy Mater Sol Cells 194(1):28-35

7. Xiao S, Zhou J, Huang S et al. Highly textured conductive and transparent ZnO films for HIT solar cell applications[J]. Journal of Physics D Applied Physics, 2015, 48(30)

8. Morisset A, Cabal R, Grange B et al (2019) Highly passivating and blister-free hole selective polysilicon based contact for large area crystalline silicon solar cells[J]. Sol Energy Mater Sol Cells 200(15):109912

9. Hintzsche LE, Fang CM, Marsman M et al (2015) Formation of a Positive Fixed Charge at c - Si (111)/a - $\mathrm{Si}_{3} \mathrm{~N}_{3.5}: \mathrm{H}$ Interfaces[J]. Phys Rev Appl 3(6):064005

10. Liu W, Yang X, Kang J et al (2019) Polysilicon Passivating Contacts for Silicon Solar Cells: Interface Passivation and Carrier Transport Mechanism[J]. ACS Appl Energy Mater 2(7):4609-4617

11. Bansal A, Srivastava P, Singh BR (2015) On the surface passivation of c-silicon by RF sputtered $\mathrm{Al}_{2} \mathrm{O}_{3}$ for solar cell application[J]. J Mater Sci: Mater Electron 26(2):639-645

12. Blakers A (2019) Development of the PERC Solar Cell[J]. IEEE J Photovolt 9(3):629-635

13. Hsu CH, Cho YS, Wu WY,, et al (2019) Enhanced Si Passivation and PERC Solar Cell Efficiency by Atomic Layer Deposited Aluminum Oxide with Two-step Post Annealing[J]. Nanoscale Res Lett $14: 139$

14. Liu PK, Cheng YL, Wang L et al. Crystalline Silicon PERC Solar Cell with Ozonized AlOx Passivation Layer on the Rear Side[J]. International Journal of Photoenergy, 2020, 2020:6

15. Allen TG, Bullock J, Yang X (2019) Passivating contacts for crystalline silicon solar cells[J]. Nature Energy 4:914-928 
16. Gakis GP, Vahlas C, Vergnes H et al (2019) Investigation of the initial deposition steps and the interfacial layer of Atomic Layer Deposited (ALD) Al2O3 on Si[J]. Appl Surf Sci 492:245-254

17. Ye F, Yuan N, Ding $J$ et al (2015) The performance of thin industrial passivated emitter and rear contacts solar cells with homogeneous emitters[J]. J Renew Sustain Energy 7(1):013122

18. Schulman JN (1998) Extension of Tsu-Esaki model for effective mass effects in resonant tunneling[J]. Applied physics letters 72(22):2829-2831

19. Physics and Technology of Amorphous-Crystalline Heterostructure Silicon Solar Cells, edited by W. G. J. H. M. van Sark, L. Korte, and F. Roca (Springer Berlin, Heidelberg, 2012), Chap. 4

20. Huang R, Yu M, Yang Q et al (2020) Numerical simulation for optimization of an ultra-thin n-type WS2/p-type c-Si heterojunction solar cells[J]. Comput Mater Sci 178:109600

21. Vexler MI, Tyaginov SE, Shulekin AF (2005) Determination of the hole effective mass in thin silicon dioxide film by means of an analysis of characteristics of a MOS tunnel emitter transistor[J]. J Phys: Condens Matter 17(50):8057

22. Huang $H$, Modanese $C$, Sun $S$ (2018) Effective passivation of $p+$ and $n+$ emitters using SiO2/Al2O3/SiNx stacks: Surface passivation mechanisms and application to industrial p-PERT bifacial Si solar cells [J]. Sol Energy Mater Sol Cells 186:356-364

23. Hoex B, Gielis JJH, Van de Sanden MCM et al (2008) On the c-Si surface passivation mechanism by the negative-charge-dielectric $\mathrm{Al}_{2} \mathrm{O}_{3}[\mathrm{~J}]$. J Appl Phys 104(11):113703

24. Li J, Wang Y, Wan F et al (2020) Passivation via atomic layer deposition Al2O3 for the performance enhancement of quantum dot photovoltaics[J]. Sol Energy Mater Sol Cells 209(1):110479

25. Lee CY, Deng S, Zhang T et al (2018) Evaluating the impact of thermal annealing on c-Si/Al2O3 interface: Correlating electronic properties to infrared absorption [J]. AIP Adv 8:075204

26. Hezel R, Jaeger K (1989) Low-temperature surface passivation of silicon for solar cells[J]. J Electrochem Soc 136(2):518-523

27. Banerjee S, Das MK (2021) A review of Al2O3 as surface passivation material with relevant process technologies on c-Si solar cell[J]. Opt Quant Electron 60:53

28. Li S, Yang N, Yuan X et al (2019) Plasma-induced damage and annealing repairing in ALDAl203/PECVD-SiNx stack[J]. Mater Sci Semicond Process 100:214-219

29. Roy AM, Lin J, Saraswat KC. The effect of fixed charge in tunnel-barrier contacts for Fermi-level depinning in germanium[J]. Electron Device Letters, IEEE, 2012, 33(6): 761-763

30. Bersch E, Rangan S, Bartynski RA et al (2008) Band offsets of ultrathin high-k oxide films with Si[J]. Physical review B 78(8):085114

\section{Figures}



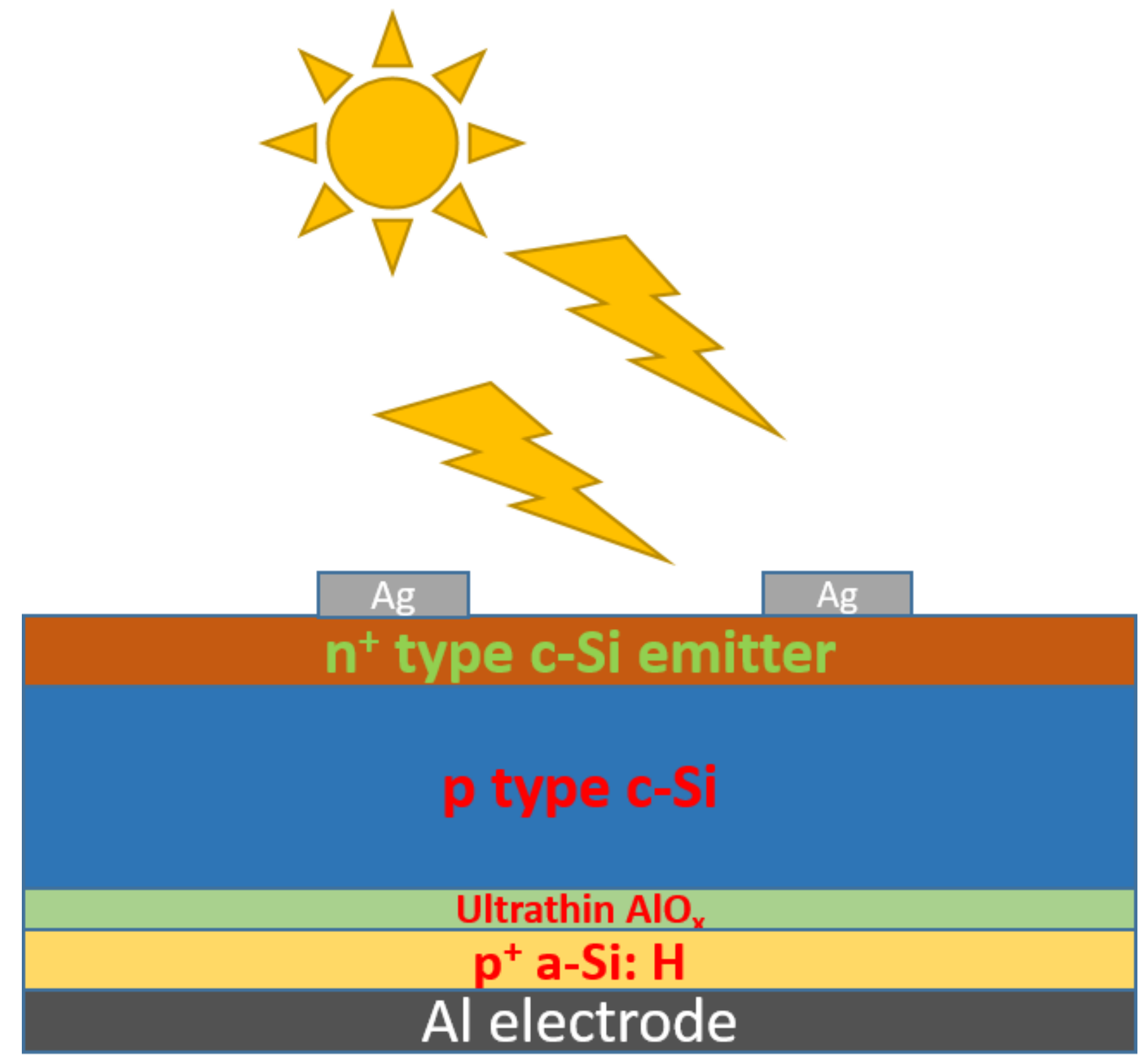

Figure 1

Schematic of simulated p-type HJ solar cell. 


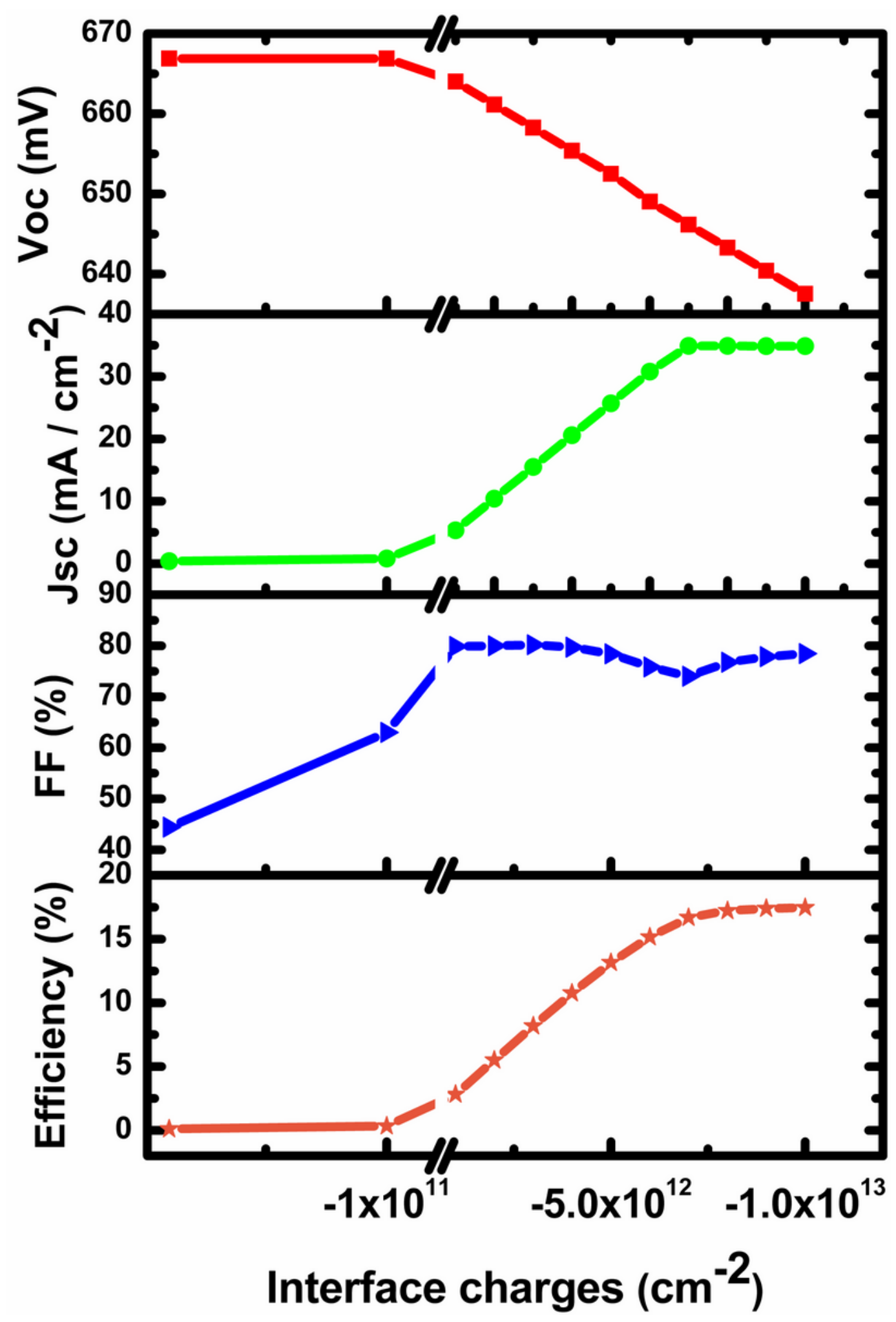

Figure 2

Output parameters of simulated HJ cell versus negative interface charges (Qit). Bandgap, Al2O3 thickness and interface defect density were fixed at $6.4 \mathrm{eV}, 1 \mathrm{~nm}$ and $1011 \mathrm{~cm}-2$, respectively. 


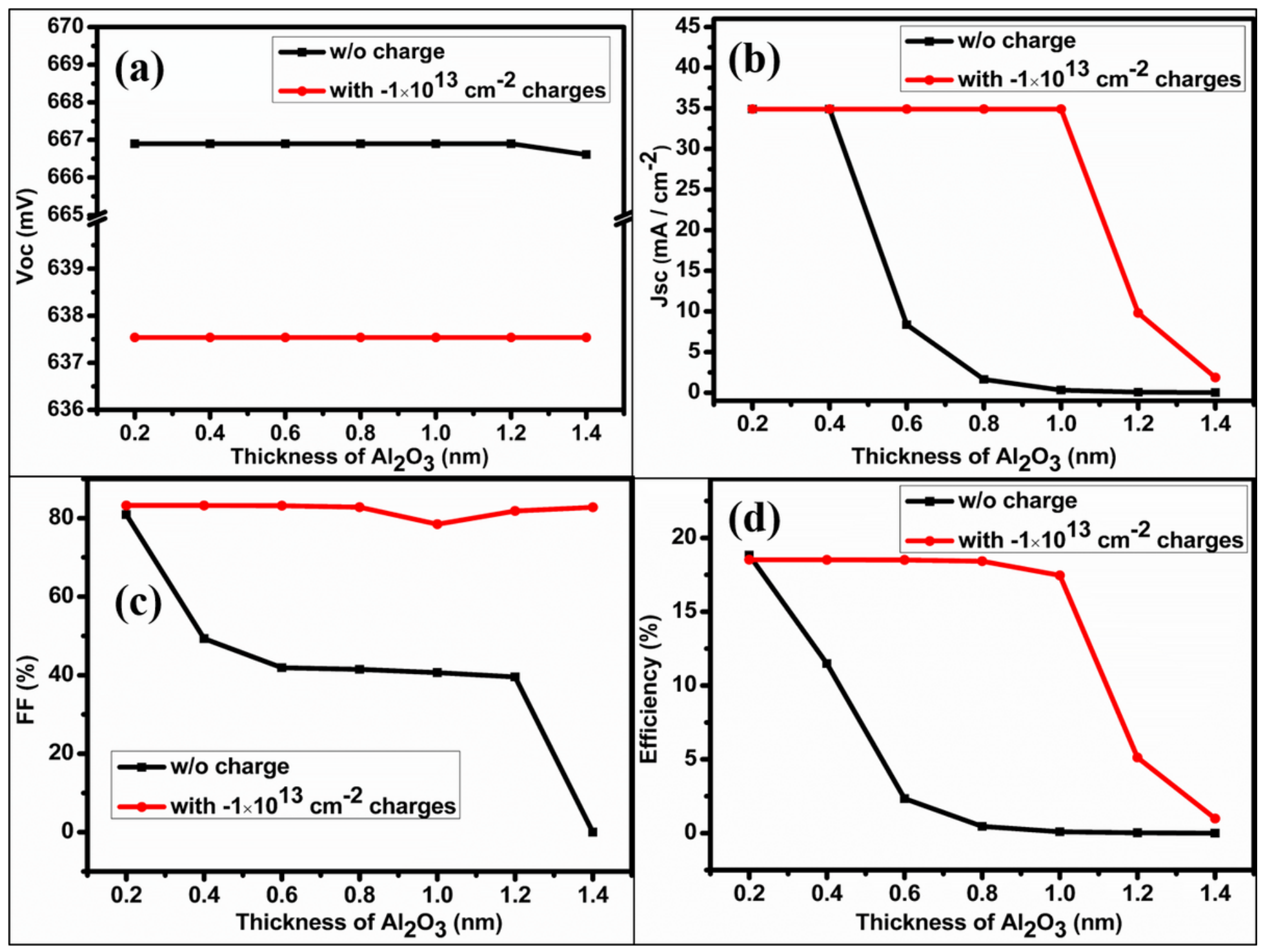

Figure 3

Influence of Al2O3 thickness on simulated HJ cell's output parameters. Bandgap, interface charges and interface defect density were fixed at $6.4 \mathrm{eV},-1013 \mathrm{~cm}-2$ and $1011 \mathrm{~cm}-2$, respectively. 


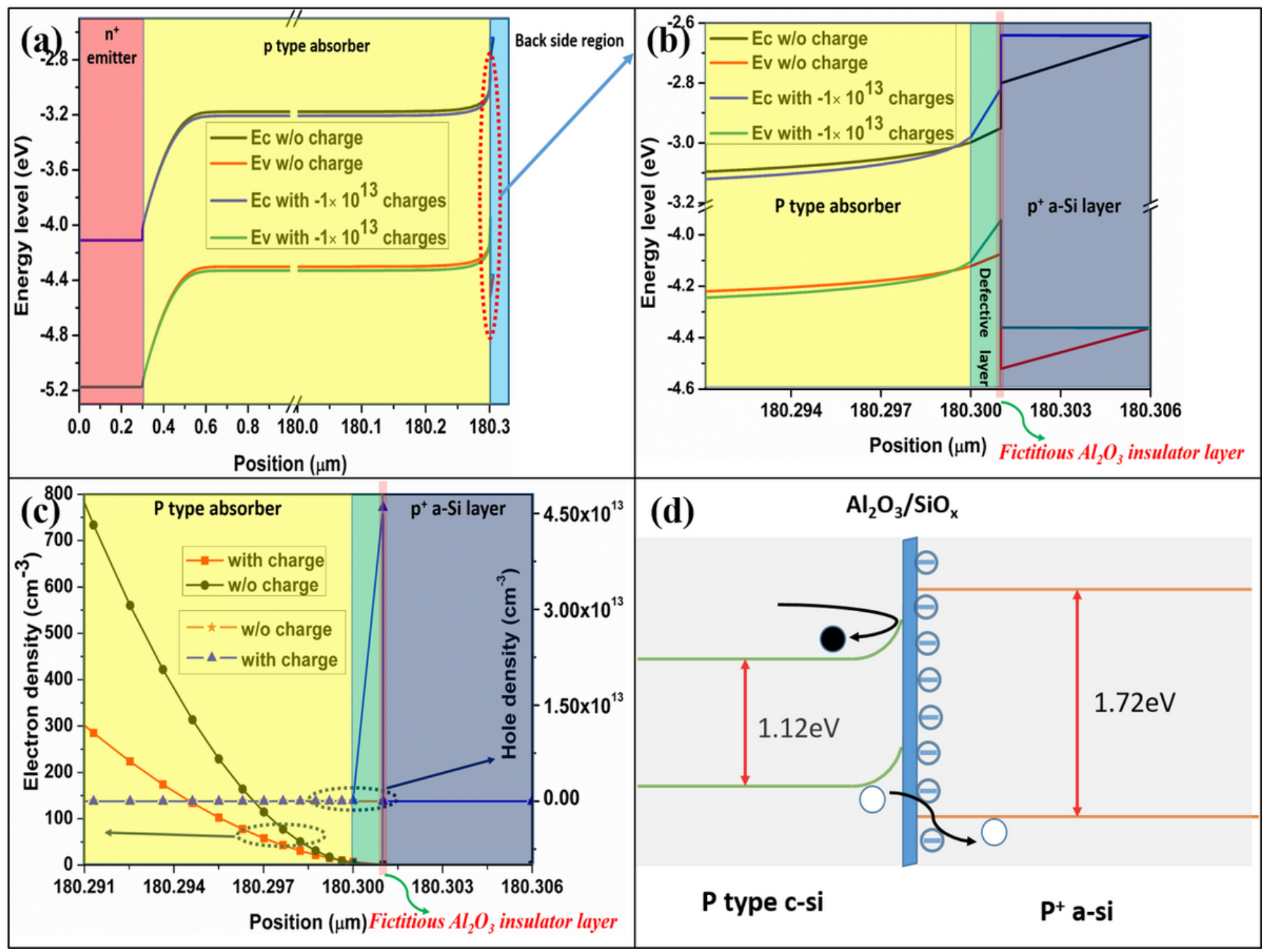

Figure 4

(a) Calculated band diagram for the entire simulated cell; (b) band diagram of enlarged backside in the simulated cell; (c) carrier density changing with position in the enlarged backside of the simulated cell; (d) schematic band diagram illustrating how the charged Al203 layer affecting the transport behavior of electrons and holes. 


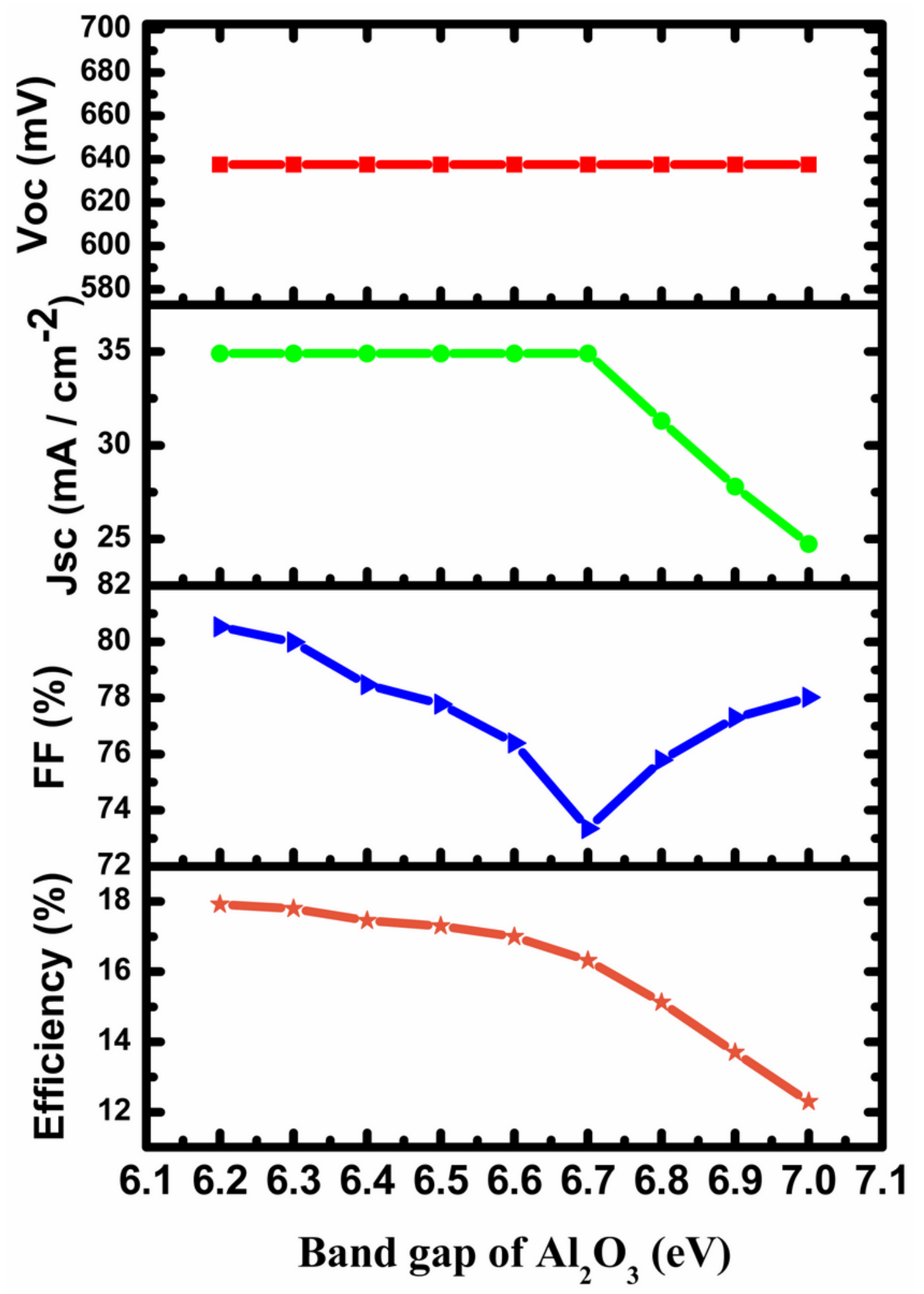

Figure 5

Influence of Al2O3 bandgap on simulated HJ cell's output parameters. The thickness of Al2O3, interface charges and interface defect density were fixed at $1 \mathrm{~nm},-1013 \mathrm{~cm}-2$ and $1011 \mathrm{~cm}-2$, respectively. 


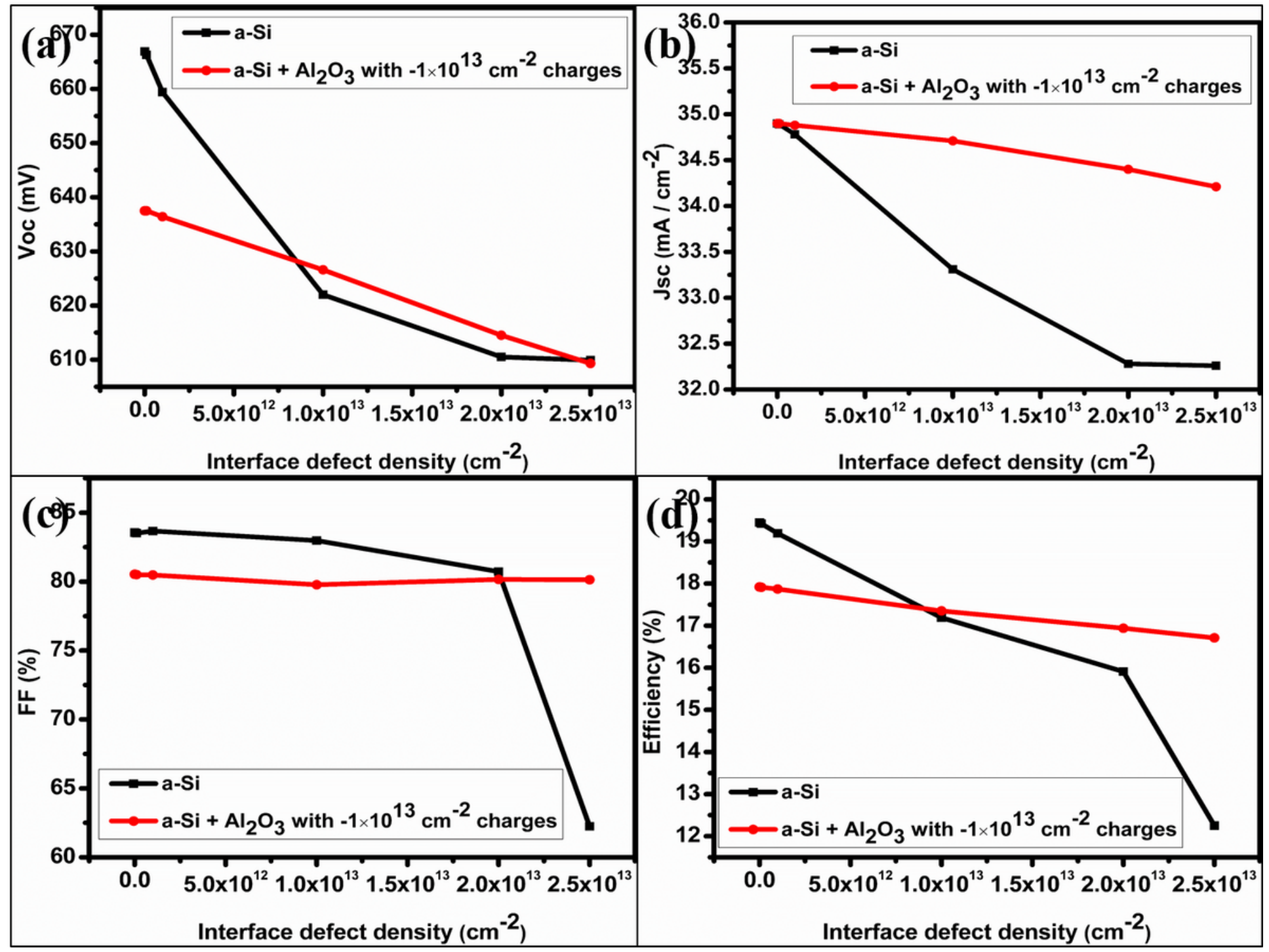

Figure 6

Simulated HJ cells' output parameters versus interface defect density (Dit). Bandgap and the thickness of Al2O3 were fixed at $6.2 \mathrm{eV}$ and $1 \mathrm{~nm}$, respectively.

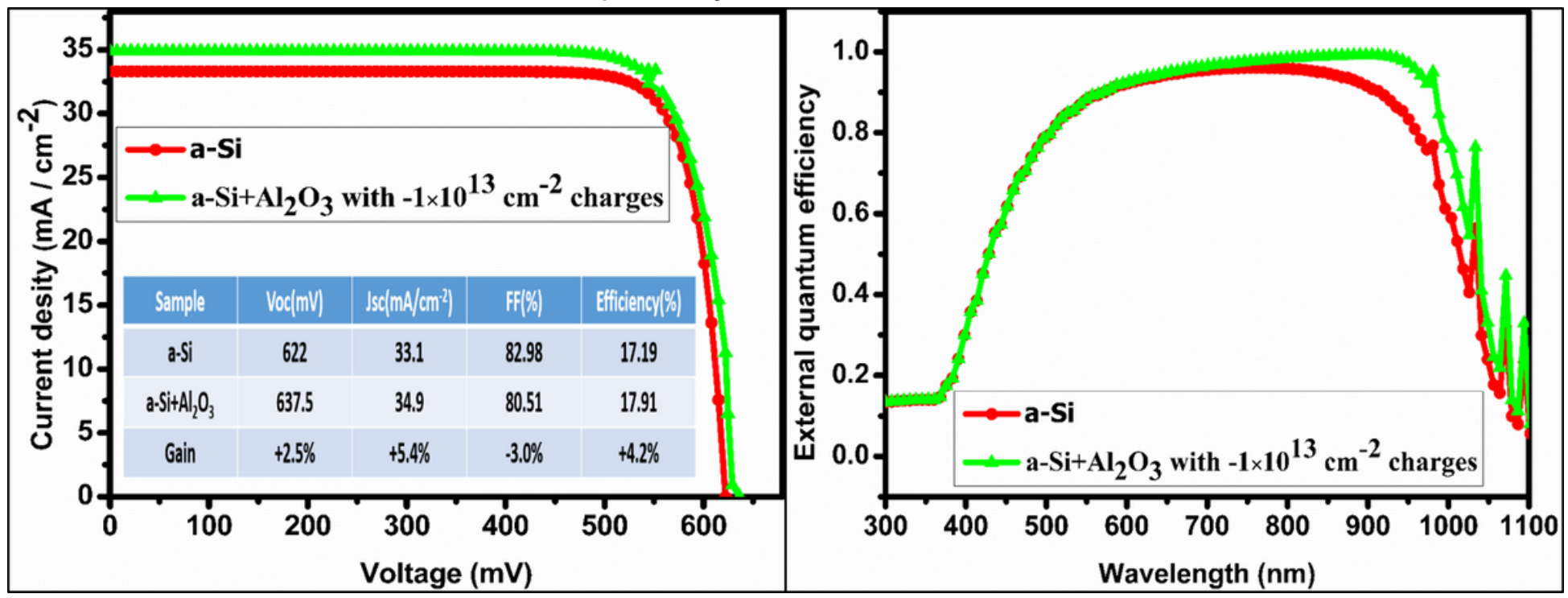


Figure 7

(a) Comparison of the I-V characteristics of a simulated cell with only a-Si and with a-Si plus Al2O3 (Qit = $-1 \times 1013 \mathrm{~cm}-2)$ at c-Si/p+ a-Si interface, the inset table shows the detail of both simulated cells and (b) the external quantum efficiency (EQE) of a simulated cell with only a-Si and with a-Si $+\mathrm{Al} 2 \mathrm{O} 3$ (Qit = $-1 \times 1013 \mathrm{~cm}-2)$ at c-Si/p+ a-Si interface.

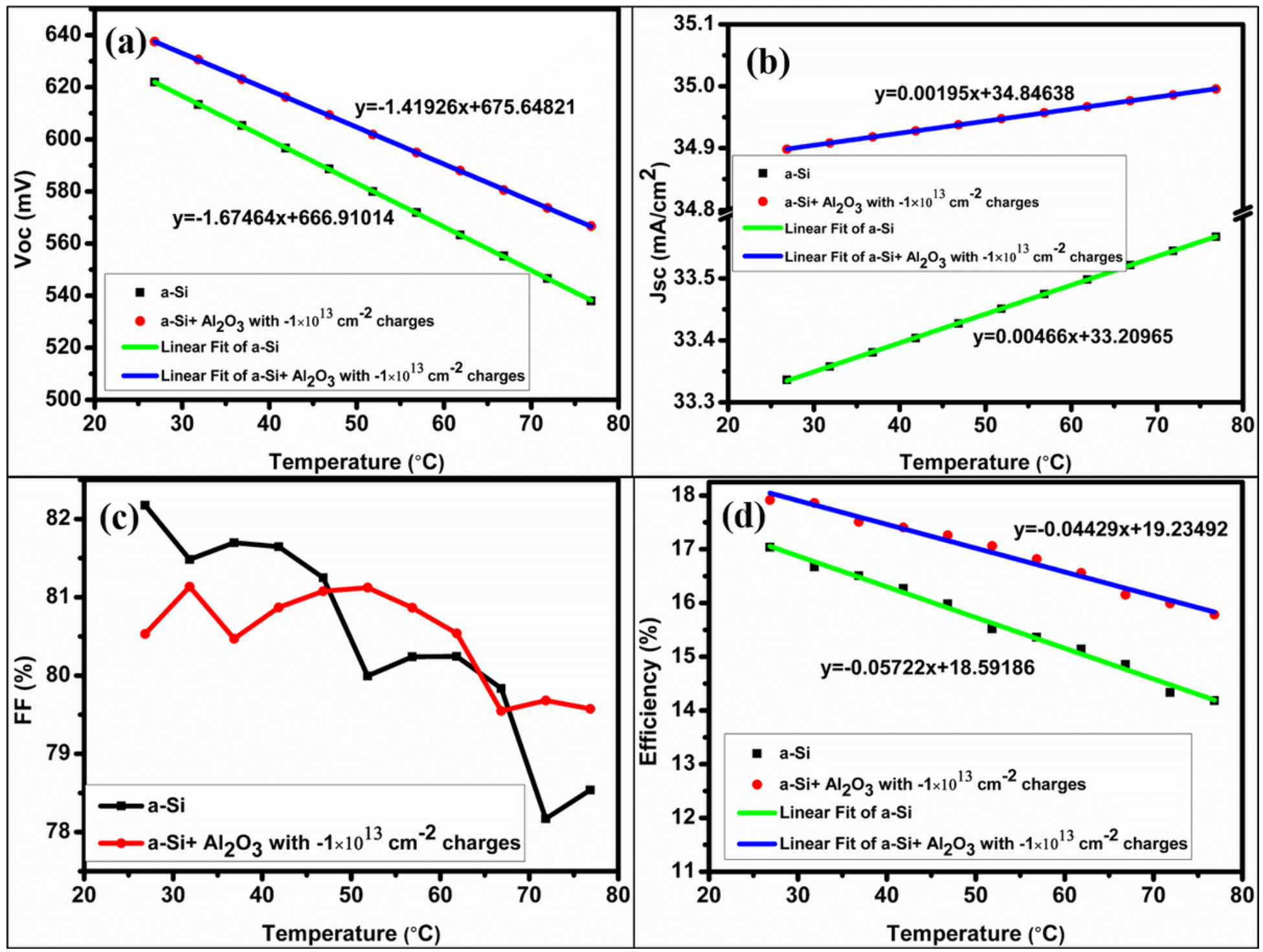

Figure 8

The temperature dependence of (a) Voc, (b) Jsc, (c) FF and (d) efficiency. 